\title{
4 \\ The First Prerequisite: Reduce Reliance on Imprisonment
}

\section{Introduction}

When the United Nations (UN) Human Rights Committee (HR Committee) provided its Concluding Observations in its periodic report on Australia in December 2017, the first concern it listed about imprisonment was overcrowding. ${ }^{1}$ The first of the HR Committee's six recommendations was that Australia '[e]liminate overcrowding in places of detention, including by increasing resort to non-custodial alternative measures to detention'. ${ }^{2}$ Therefore, it is appropriate that the first prerequisite in this book is to reduce reliance on imprisonment, which is the best way to reduce overcrowding.

An alternative method for addressing overcrowding would, of course, be to continue to expand the number of prisons so that there is plenty of space for more people to be imprisoned. However, even if governments were willing to allocate the necessary expenditure to such an endeavour, which they have not been to date, this is hardly desirable. It would not accord with the strong emphasis international human rights law places on the prohibition of torture or cruel, inhuman or degrading treatment

1 Human Rights Committee, Concluding Observations on the Sixth Periodic Report of Australia, UN Doc CCPR/C/AUS/CO/6 (1 December 2017) 8.

2 Ibid [42](a). 
or punishment. ${ }^{3}$ Australia's 2017 ratification of the Optional Protocol to the Convention against Torture and Other Cruel, Inhuman or Degrading Treatment or Punishment (OPCAT), which sets in place mechanisms for preventing the occurrence of practices falling within this definition in prisons, gives further weight to this argument. ${ }^{4}$ Given the nature of prisons as 'total institutions' and the 'pains of imprisonment' outlined in Chapter 1, the best way to prevent people potentially being subjected to such practices is to keep them out of prison. This is recognised by the Subcommittee for the Prevention of Torture and Other Cruel, Inhuman or Degrading Treatment or Punishment (SPT) (the UN expert committee established by the OPCAT) in its guiding principles, which note that 'detention conditions ... in some circumstances can also be a means of torture. ${ }^{5}$ This has led some scholars to argue that prisons should be abolished entirely. ${ }^{6}$

The human rights violations that are more likely to occur in overcrowded prisons are detailed in this chapter (under 'Prison Overcrowding and Human Rights Violations') and clearly demonstrate that reducing reliance on imprisonment is essential as a prerequisite for human rights compliance in Australian prisons. This chapter then turns to three strategies for achieving this goal. The first is prison abolition, and is dealt with relatively briefly here given the overwhelming political challenges it presents. A discussion of two other, more politically feasible strategiesjustice reinvestment and a reductionist prison policy-follows.

3 International Covenant on Civil and Political Rights, opened for signature 19 December 1966, 999 UNTS 171 (entered into force 23 March 1976) art 7 ('ICCPR'); Convention against Torture and Other Cruel, Inhuman or Degrading Treatment or Punishment, opened for signature 10 December 1984, 1465 UNTS 85 (entered into force 26 June 1987) ('CAT'); Convention on the Rights of Persons with Disabilities, opened for signature 30 March 2007, 2515 UNTS 3 (entered into force 3 May 2008) art 15 ('CRPD').

4 Optional Protocol to the Convention against Torture, adopted 18 December 1992, UN Doc A/ RES/57/199 (entered into force 22 June 2006) ('OPCAT'). The OPCAT also applies to other places of detention: see art 4(2).

5 Subcommittee for the Prevention of Torture and Other Cruel, Inhuman or Degrading Treatment or Punishment, The Approach of the Subcommittee on Prevention of Torture to the Concept of Prevention of Torture and Other Cruel, Inhuman or Degrading Treatment or Punishment Under the Optional Protocol to the Convention Against Torture and Other Cruel, Inhuman or Degrading Treatment or Punishment, CAT/ OP/12/6 (30 December 2010) 5(d).

6 See, eg, Angela Davis, Are Prisons Obsolete? (Seven Stories Press, 2003); Thomas Mathieson, 'The Politics of Abolition' (1986) 10 Contemporary Crises 81. 
Justice reinvestment was recommended by the Australian Law Reform Commission (ALRC) as a useful strategy for dealing with overimprisonment of Indigenous Australians in 2017.7 A reductionist prison policy is a response that is contained within the criminal justice system itself and does not require the wholesale social change that both prison abolition and justice reinvestment would necessitate. It is the most feasible of the three strategies. Therefore, the way that a reductionist prison policy could be implemented in Australia is the final topic of this chapter (under 'Application of a Reductionist Policy in Australia').

\section{Prison Overcrowding and Human Rights Violations}

The Australian prison population is growing, and this growth is consistent across all jurisdictions (as outlined in Chapter 1). In 2018 alone, male imprisonment rose by 4 per cent and female imprisonment rose by 10 per cent. ${ }^{8}$ Most Australian jurisdictions are expanding their prison capacity. New South Wales (NSW) has recently opened two 'rapid build' prisons that house imprisoned people in dormitories, adding 1,044 beds in the 2017-18 financial year. ${ }^{9}$ Victoria opened a new 1,000-bed prison in $2017 .{ }^{10}$ Western Australia (WA) has built two new prisons. ${ }^{11}$ The Australian Capital Territory (ACT) has added 120 beds to the Alexander Maconochie Centre (the sole adult prison in the ACT, which accommodates both men and women). ${ }^{12}$ Despite these expansion efforts, prison infrastructure has at times failed to keep pace with the growth in prison population. The Queensland Productivity Commission estimated that it would cost $\$ 3.6$ billion dollars by 2025 to increase the capacity of the Queensland prison system to meet the current shortfall. ${ }^{13}$

7 Australian Law Reform Commission (ALRC), Pathways to Justice-An Inquiry into the Incarceration Rate of Aboriginal and Torres Strait Islander Peoples, Report No 133 (2017) 137-8, Recommendations 4-1, 4-2.

8 Australian Bureau of Statistics, Prisoners in Australia 2018 (6 December 2018). For a longerterm perspective see Don Weatherburn, 'Australian Imprisonment 2002-2016: Crime, Policing and Penal Policy' (2018) 51(4) Australian \& New Zealand Journal of Criminology 537.

9 NSW Government, Department of Justice Annual Report $2017-18$ (2018) 52-3.

10 Minister for Corrections, 'Ravenhall Correctional Centre Officially Opened' (Media Release, 12 October 2017).

11 Office of the Inspector of Custodial Services (OICS), Western Australia's Prison Capacity (2016) i.

12 Lorana Bartels, 'The ACT Prison: Human Rights Rhetoric Versus Crowded and Bored Reality'

(2015) 9 Court of Conscience 13, 16.

13 Queensland Productivity Commission, Inquiry into Imprisonment and Recidivism. Final Report (2019) x. 
Despite prison capacity expansion, prisons are exceeding the number of people they are designed to house. They are overcrowded. The Productivity Commission reported in 2018 that secure facilities were operating at 121.2 per cent of capacity in 2016-17 (the most recent year for which a reliable national rate is available), ${ }^{14}$ with West Australian secure prisons operating at 132.8 per cent capacity in $2018-19 .{ }^{15}$

Overcrowding has led some jurisdictions to use shipping containers to cope with their expanding prison populations. This has occurred in South Australia, WA and Victoria. ${ }^{16}$

A good overview of the multitude of problems associated with overcrowding is provided by the NSW Inspector of Custodial Services inspection standards:

Overcrowding can have significant detrimental effects on the standard of living, regime and safety within a correctional centre. An overcrowded correctional centre may entail cramped and unhygienic accommodation, a constant lack of privacy, reduced out of cell activities, demand outstripping the capacity of staff and facilities, overburdened health care services, increased tension and potentially increased levels of violence. ${ }^{17}$

The major implication of overcrowding is people having to share cells that are not designed to accommodate the number of people placed in them. For instance, in WA, there have been situations where two people have had to share cells designed for one person, and of cells designed for three people accommodating four to six people. ${ }^{18}$ Moreover, triple bunking has

14 Steering Committee for the Review of Government Service Provision, Report on Government Services 2018, Volume C: Justice (Commonwealth of Australia, 2018) 8.14, Table 8A.13. The figure is 115.6 per cent for 2017-2018 but Victoria, New South Wales (NSW) and South Australia did not provide data and, given Victoria and NSW operate two of the larger prison systems in Australia, this skews the data: Steering Committee for the Review of Government Service Provision, Report on Government Services 2019, Part C: Justice (Commonwealth of Australia, 2019) 8.17.

15 Steering Committee for the Review of Government Service Provision, Report on Government Services 2020, Volume C: Justice (Commonwealth of Australia, 2020) Table 8A.13.

16 Elizabeth Grant, "Pack 'em, Rack 'em and Stack 'em”: The Appropriateness of the Use and Reuse of Shipping Containers for Prison Accommodation' (2013) 13(2) Australasian Journal of Construction Economics and Building 35, 37-8 (in relation to SA), 36 (in relation to WA); Jane Lee, 'Prisoners Moved into Shipping Containers', The Age (Victoria), 6 January 2014; Margaret Paul, 'More Shipping Containers Cells Purchased to Accommodate Growing Prisoner Population', $A B C$ News (Australia), 9 April 2014.

17 NSW Inspector of Custodial Services, Inspection Standards for Adult Custodial Services in New South Wales (2014) 27, Standard 21.1.

18 OICS, Report of an Announced Inspection of Greenough Regional Prison (2013) 26. 
occurred in Victorian prisons. ${ }^{19}$ In NSW, where imprisoned people are housed in dormitories in two new prisons, all of the same concerns apply and are amplified.

Sharing cells is contrary to Rule 12 of the UN Standard Minimum Rules for the Treatment of Prisoners (the Nelson Mandela Rules) ('the Mandela Rules'), which stipulates:

[w] here sleeping accommodation is in individual cells or rooms, each prisoner shall occupy by night a cell or room by himself or herself. If for special reasons, such as temporary overcrowding, it becomes necessary for the central prison administration to make an exception to this rule, it is not desirable to have two prisoners in a cell or room. ${ }^{20}$

The Mandela Rules do not specify how much space each person is to be provided with in prison and nor do the 2018 Guiding Principles for Corrections in Australia ('Guiding Principles'). The superseded 2012 Standard Guidelines for Corrections in Australia ('Guidelines') referred to the cell size being consistent with the 'Standard Guidelines for Prison Facilities in Australia and New Zealand (1990)'. ${ }^{21}$ The Office of the Inspector of Custodial Services (OICS) in WA summarises these requirements as follows:

The Standard Guidelines for Prison Facilities in Australia and New Zealand 1990 (Australasian Standard Guidelines 1990) provide that a single person cell without ablution facilities (toilet, shower, and basin) should be a minimum of $7.5 \mathrm{~m}^{2}$ ('dry cells'). An additional $1.25 \mathrm{~m}^{2}$ is required for cells that include ablution facilities ('wet cells'). If a cell is to be shared, a further $4.0 \mathrm{~m}^{2}$ is required for each additional person. ${ }^{22}$

19 Victorian Auditor-General, Prison Capacity Planning (2012) 15.

20 United Nations Standard Minimum Rules for the Treatment of Prisoners (the Nelson Mandela Rules), UN Doc A/RES/70/175 (17 December 2015) ('the Mandela Rules').

21 The Corrective Services Ministers' Conference (Cth), Standard Guidelines for Corrections in Australia ( $3^{\text {rd }}$ ed, 2004) 2, Guideline 2.3 ('Guidelines').

22 OICS, above n 11, 10. 
Following an assessment of prison cells in WA, the OICS concluded that 'only one third of prisoners can be held in conditions that comply with Australasian Standard Guidelines for Corrections for cell size ... the practice of routinely double bunking single cells is in breach of the "Mandela Rules"'. ${ }^{23}$

Cell sharing raises a number of concerns. First, people have far less than the recommended seven square metres of space each. This is particularly problematic when imprisoned people spend as much time in their cells as they do in Australian prisons. The national average of time spent out of cells is nine hours per day and, in some jurisdictions, it is less (eg, 7.2 hours per day in NSW and 7.7 hours in Tasmania and SA). ${ }^{24}$

Second, overcrowding in cells leads to the violation of the right to be treated with humanity and respect, and the prohibition of torture, cruel, inhuman and degrading treatment or punishment. This is clear from individual communications to the HR Committee. Part of the responsibility of the HR Committee is to consider whether the circumstances complained of in individual communications constitute violations of arts 7 and 10(1) of the International Covenant on Civil and Political Rights (ICCPR) by state parties. ${ }^{25}$ As there have been no communications to the HR Committee concerning overcrowding in Australian prisons, some examples from other countries are illustrative.

In a prison in the Philippines, a complainant was accommodated in a dormitory with over 200 others where violence was 'acquiesced in by the prison authorities'. This, in the view of the HR Committee, amounted to violations of both articles. ${ }^{26}$ Similarly, a complaint concerning conditions in a prison in the Dominican Republic saw the HR Committee find that both articles had been violated due to the following circumstances: ${ }^{27}$

23 Ibid v, 10-15.

24 These figures are for secure prisons. Steering Committee for the Review of Government Service Provision, above n 15, Table 8A.13.

25 The prohibition of 'torture, cruel, inhuman or degrading treatment or punishment' (art 7) and the requirement that '[a]ll persons deprived of their liberty shall be treated with humanity and with respect for the inherent dignity of the human person' (art 10(1)).

26 Human Rights Committee, Views: Communication No 868/99, UN Doc CCPR/C/79/D/ 868/1999 (30 October 2003) ('Wilson v The Philippines') [2.4]-[2.5], [7.3].

27 Human Rights Committee, Views: Communication No 188/84, UN Doc CCPR/C/31/D/ 188/1984 (5 November 1987) ('Portorreal v Dominican Republic') [11]. 
Later the same day, the author was allegedly separated from the other political opposition leaders and transferred to another cell (known as the 'Viet Nam cell'), measuring 20 by 5 metres, where approximately 125 persons accused of common crimes were being held. Conditions were allegedly inhuman in this overcrowded cell, the heat was unbearable, the cell extremely dirty and owing to lack of space some detainees had to sit on excrement. ${ }^{28}$

In the Australian context, concerns about these rights have been referred to in reports by monitoring bodies such as the OICS: ' $t \mathrm{t}$ ] oilets in shared cells are unscreened and there is no dignified way to use them in front of another person. This presents particular problems at night when prisoners are locked in cells for 12.5 hours or more' ${ }^{29}$ These matters are discussed further in Chapter 7.

Third, there is an increased risk of intimidation, bullying and violence. This was reflected in the now superseded 2012 Guidelines, which stipulated the following requirements in relation to sharing of cells to protect against such risks: 'Where prisoners are accommodated in multiple occupancy cells or rooms, the prisoners are to be carefully assessed and selected as being suitable to associate with one another in those conditions. Particular care should be taken to avoid prisoners being subjected to intimidation or bullying' ${ }^{30}$

It was difficult to establish whether this policy is being followed in practice because there was no reporting requirement stipulated in the Guidelines. While the 2018 Guiding Principles contain 40 principles relating to 'safety and security', none of these specifically refer to the potential risk of intimidation, bullying and violence caused by cell sharing in the way that the 2012 Guidelines did. $^{31}$ There is a very broad principle pursuant to which this risk might be taken into account by prison managers: 'Prisoners are assessed and allocated to accommodation compatible with their assessed risks and needs to ensure their safety and security and the good order of the facility'. ${ }^{32}$

28 Ibid [2.2].

29 OICS, above n $11,15$.

30 Guidelines, above n 21, 24.

31 Corrective Services Administrators' Conference (Cth), Guiding Principles for Corrections in Australia (2018) 15-19.

32 Ibid 18, Principle 3.3.2. 
In light of the high levels of violence in prisons generally (irrespective of cell sharing) (as outlined in Chapter 1), combined with Steels and Goulding's finding that shared cells are one of the places in prisons where the risk of sexual assault is highest, it seems more likely than not that 'intimidation or bullying', or worse, is occurring. ${ }^{33}$

While the NSW dormitory prisons have not been in operation for long, there were concerns expressed about safety during a recent parliamentary committee inquiry:

Inmates were strongly opposed to the dormitory style accommodation, in which older and quieter inmates must co-reside with younger, more troublesome inmates. For some, there is a fear of being attacked or assaulted in their sleep, especially as there is a no transfer policy between pods, such that 'there is no escaping the threats and abuse'. ${ }^{34}$

Overcrowding raises some other concerns, in addition to those raised by cell sharing. There is evidence from Victorian prisons that as the prison population has increased the rate of assaults and self-harm has also increased. ${ }^{35}$ The Victorian Auditor-General has documented this as follows:

The increase in prisoner numbers and overcrowding within prisons and management cells has coincided with an increase in prisoner incidents over the past six years. The rate of serious incidents per prisoner, such as assaults, attempted suicides and self-mutilation, has almost doubled over this time. ${ }^{36}$

Overcrowding puts pressure on services for imprisoned people, including medical care, means of communicating with family members (such as telephones), education and programs to facilitate their rehabilitation (such as drug and alcohol programs). The difficulty of providing health

33 Protection units contain a high concentration of people convicted of sex offences because they need protection from those in mainstream units and they may victimise others in the protection unit: Brian Steels and Dot Goulding, Predator or Prey? An Exploration of the Impact and Incidence of Sexual Assault in West Australian Prisons (November 2009) 50-1.

34 New South Wales, Parliament Legislative Council Portfolio Committee No. 4 - Legal Affairs, Parklea Correctional Centre and Other Operational Issues (2018) 80. The Committee also heard evidence about problems with dormitory-style prison accommodation overseas and in juvenile detention centres in Australia: ibid 85-6.

35 By 40 per cent in the last 10 years: Sentencing Advisory Council, Victoria's Prison Population 2002-2012 (2013).

36 Victorian Auditor-General, above n 19, xii. 
care in overcrowded prisons has been recognised by the Australian Institute of Health and Welfare. The Institute has noted that, in response to overcrowding, imprisoned people are frequently being transferred between facilities, action that makes 'continuing health care more difficult'. ${ }^{37}$ Overcrowding has had an impact on the operation of Victoria's residential drug program ${ }^{38}$ and there has been pressure put on telephone services in NSW prisons, with the NSW Inspector of Custodial Services giving the illustration of a prison with one telephone shared between 48 imprisoned people. ${ }^{39}$

The dangers to prison health care services that can result from overcrowding should not be underestimated and are starkly illustrated by a decision of the United States Supreme Court in 2011. Severe overcrowding in Californian prisons had resulted in people with mental illness not receiving adequate treatment. The situation was so dire that there were 68 preventable deaths in a year. People were waiting for 12 months to receive mental health treatment and some mentally ill people were held in cages while awaiting treatment. ${ }^{40}$ The Supreme Court held that this violated the United States Constitution Eighth Amendment (prohibition of cruel and unusual punishment). ${ }^{41}$

Overcrowding can increase the risk of riots, which pose obvious risks to the safety of all people imprisoned (as well as staff) at the time of the riot. Overcrowding was described as a 'contributing factor' in an independent investigation of the causes of a riot in a Victorian prison that occurred in $2015 .{ }^{42}$ The OICS noted this as a risk of overcrowding in a 2016 report and referred to riots in WA prisons in 2013, 1998 and $1988 .{ }^{43}$

37 Australian Institute of Health and Welfare, The Health of Australian Prisoners 2018 (2019) 7.

38 Victorian Ombudsman, Investigation into the Rehabilitation and Reintegration of Prisoners in Victoria (2015) 59.

39 NSW Inspector of Custodial Services, Full House: The Growth of the Inmate Population in NSW (2015) 12. See also OICS, above n 11, 19. Lack of access to telephones is also a problem in the Alexander Maconochie Centre in the ACT and in Western Australian prisons: ACT Inspector of Correctional Services, Review into the Treatment and Care of Remandees at the Alexander Maconochie Centre (2018) 54-5; OICS, Contact with Family and Friends While in Custody (2018).

40 Alicia Bower, 'Unconstitutionally Crowded: Brown v Plata and How the Supreme Court Pushed Back to Keep Prison Reform Litigation Alive' (2012) 45 Loyola of Los Angeles Law Review 555, 556-7. 41 Brown v Plata, unreported, Supreme Court of the United States, 23 May 2011. See also Ian Freckelton, 'Cruel and Unusual Punishment of Prisoners with Mental Illnesses: From Oates to Plata' (2011) 18(3) Psychiatry, Psychology and Law 329, 329.

42 Independent Investigation into the Metropolitan Remand Centre Riot, Final Report (December 2015) 7. The introduction of a smoking ban in Victorian prisons was another contributing factor, as noted in Chapter 1.

43 OICS, above n 11, 20. 
It is clear that overcrowded prisons lead to human rights violations of imprisoned people. They also exacerbate the 'pains of imprisonment', as outlined in Chapter 1.

\section{Strategies to Reduce Reliance on Imprisonment}

The most radical strategy for resolving the problems outlined above is to abolish prisons. Given this response is unlikely to be pursued, alternative responses need to be explored. Justice reinvestment and a reductionist prison policy instead focus on minimising the use of imprisonment to the greatest extent possible. These three strategies are discussed below.

\section{Prison Abolition}

The prison abolition literature suggests that prisons would not be needed if society was transformed in such a way that alternative mechanisms were used to deal with vulnerabilities such as mental illness. In a similar vein to other abolition movements (eg, the abolition of slavery), prison abolitionists have developed a vision of society without prisons and with much lower crime rates. Scott describes this as an 'abolitionist real utopia'. ${ }^{44}$ This vision involves large-scale social changes, including:

- greater investment in schools as they provide 'the most powerful alternative to jails ${ }^{45}$

- decriminalisation of drug use, with community-based drug treatment made freely available on a voluntary basis ${ }^{46}$

- providing adequate mental health services in the community, so that people with mental illness are not imprisoned ${ }^{47}$

- where sanctions are required, basing them on 'reparation and reconciliation rather than retribution and vengeance. ${ }^{48}$

44 David Scott, 'Unequalled in Pain' in David Scott (ed), Why Prison? (Cambridge University Press, 2013) 323 .

45 Angela Davis, Are Prisons Obsolete? (Seven Stories Press, 2003) 108.

46 Ibid 108-9.

47 Ibid 108.

48 Ibid 107, 114-15. 
The changes required are large scale and broader than changes to the criminal justice system. The changes would build the sense of community, specifically the interdependency a person has with their society, including such things as their 'relationships of loyalty, trust and concern'. ${ }^{49}$ When these relationships break down, a person is more likely to commit crime. Therefore, social changes that rebuild these relationships should reduce the incidence of crime. However, it must be recognised that these changes would require a significant investment of resources, only some of which could reliably be obtained from the savings made by not operating existing prisons.

While in many ways an attractive approach to the problems caused by imprisonment, prison abolition is not a very realistic solution. Abolition scholarship has been criticised for posing a solution that may only be workable in an environment that bears practically no resemblance with modern social and political order ${ }^{50}$ and for only being potentially workable in small countries like Norway. ${ }^{51}$ There is also a very real risk that abolition would not be accompanied by the necessary social changes. A parallel example is the abolition of mental health institutions in the 1960s and 1970s which were supposed to be replaced by community care for mentally ill people. This has never been properly resourced and people do not get the support they need..$^{52}$ This is a contributing factor to the large number of mentally ill people in Australian prisons. ${ }^{53}$

However, it would be foolish to dismiss these arguments in their entirety. First, however unrealistic prison abolition may be for the general community, the types of social change identified by the prison abolition movement are essential if the harm caused by imprisonment to vulnerable segments of the population is to be addressed. Second, the prison abolition movement has both middle- and long-term aims. The long-term aim-a society without prisons-is arguably unrealistic. The middleterm aim-to minimise the expansion of prisons and 'shrink the scope

49 Rob White and Fiona Haines, Crime and Criminology (Oxford University Press, $4^{\text {th }}$ ed, 2008) 168.

50 Sebastian Scheerer, 'Towards Abolitionism' (1986) 10 Contemporary Crises 5, 15.

51 Ibid 18. Norway is where prominent abolitionist Mathieson is from.

52 See, eg, Sebastian Rosenberg et al, 'National Mental Health Reform: Less Talk, More Action' (2009) 190(4) Medical Journal of Australia 193.

53 See, eg, Paul White and Harvey Whiteford, 'Prisons: Mental Health Institutions of the 21st Century?' (2006) 185(6) Medical Journal of Australia 302. 
of criminal law to the absolutely necessary core'-is more realistic. ${ }^{54}$ It is an argument that has been made in relation to women's imprisonment in Australia (discussed below).

Mathieson puts forward eight arguments against building more prisonsarguments for achieving the middle-term aim: ${ }^{55}$

1. Prisons do not lead to individuals being less likely to commit crime upon their release. In other words, they are ineffectual at achieving the often-declared aim of individual crime prevention ${ }^{56}$

2. There is evidence that prisons do not have a general deterrent effect ${ }^{57}$

3. Overcrowding can be addressed by changing sentencing laws, releasing people earlier from prison and lowering the limit for parole eligibility ${ }^{58}$

4. Once a prison is built, it will be used for a long period of time. That is, a prison has an 'irreversible character' ${ }^{59}$

5. The prison system has an 'expansionist character'. This means individual prisons will always be full and there will always be a need to build more unless a conscious decision is made to reduce the prison population ${ }^{60}$

6. Prisons are inhumane and involve numerous 'pains' (see Chapter 1) ${ }^{61}$

7. Building more prisons 'solidified the prison solution in our society'. This is a cultural problem because it suggests that it is a 'good' solution, despite the fact that building prisons 'emphasizes violence and degradation as a method of solving inter-human conflicts' ${ }^{62}$

8. There are huge costs associated with building and operating prisons, and the money could be better spent. Mathieson describes this last as a supporting argument to his main points, rather than a standalone argument. ${ }^{63}$

54 Scheerer, above n 50, 19.

55 Many of these arguments are supported by the more recent abolitionist movement launched in the United States of America (USA) in the 1990s: see, eg, Julia Oparah, 'Why No Prisons?' in David Scott (ed), Why Prison? (Cambridge University Press, 2013) 298-300; Scott, above n 44, 320.

56 Thomas Mathieson, 'The Politics of Abolition' (1986) 10 Contemporary Crises 81, 89.

57 Ibid.

58 Ibid 90. These are 'front door' and 'back door' strategies and are discussed further in 'Reductionist Prison Policy' below.

59 Ibid $90-1$.

60 Ibid 91.

61 Ibid.

62 Ibid 92.

63 Ibid. 
Mathieson writes that these arguments constitute 'a forceful basis for advocating a policy of a permanent international ban on prison building'. ${ }^{64}$

In addition to supporting the abolitionist middle-term option, they are each worth considering in their own right. They are also consistent with the reductionist prison policy that is advocated later in this chapter. Indeed, they have had some impact on discussion about women's imprisonment.

\section{Prison Abolition in Australia}

There is potentially more political saleability to the argument that imprisonment should be abolished—or at the very least minimised—for women than there is for imprisonment overall. This is because women are predominantly sentenced for less serious criminal offences and shorter terms of imprisonment. They also frequently have a history of victimisation. There is also the need to take into account the impact that imprisonment has on the dependent children of these women (as referred to in Chapter 1). The combination of these factors has led the Law Council of Australia to suggest that most women could 'safely serve their sentences within the community'. ${ }^{65}$

A summary of the profile of different offences committed by men and women in Victoria provided by the Victorian Sentencing Advisory Council in 2010 is pertinent here and illustrative of national trends:

Men predominate in offences such as assault $(11.8 \%$ of men versus $7.5 \%$ of women), sex offences $(18.5 \%$ versus $3.5 \%)$ and unlawful entry with intent (burglary) (11.0\% versus $6.0 \%)$, while women most commonly appear in prison with property offences (including theft) (21\% of women versus $6.1 \%$ of men) and deception offences $(10.0 \%$ versus $3.1 \%){ }^{66}$

When women do commit violent offences, it has been observed that ' $[\mathrm{m}]$ ost violent offences by women are one-off events and few women are repeat violent offenders' ${ }^{67}$ The OICS in WA has found that womenparticularly Indigenous women-are over-represented among people in prison for fine default. ${ }^{68}$

64 Ibid 88.

65 Cited by Anna Kerr and Rita Shackel, 'Equality with a Vengeance: The Over-Incarceration of Women' (2018) 147 Precedent 20, 24.

66 Sentencing Advisory Council, Gender Differences in Sentencing Outcomes (2010) 60.

67 Mary Stathopoulos, 'Addressing Women's Victimisation in Custodial Settings' (ACSSA Issues No 13, Australian Institute of Family Studies, Australian Centre for the Study of Sexual Assault, 2012) 7.

68 OICS, Fine Defaulters in the Western Australian Prison System (2016) v. 
Women tend to be imprisoned for short sentences and the Victorian Sentencing Advisory Council has noted 'an increase in the number of women sentenced to short terms of imprisonment (less than one month)' ${ }^{69}$ This is particularly the case for Indigenous women, and Stathopoulos has observed that 'Indigenous women serve shorter sentences, meaning they are imprisoned for very minor offences—such as driving infringements and non-payment of fines-and that they are more likely than nonIndigenous women to be on remand'.$^{70}$

There have been calls to stop building more women's prisons, commencing with a NSW Task Force in 1985. Stubbs and Baldry summarise that:

[a]t the time, the number of women in prison in NSW had more than doubled in just two years ... The Task Force adopted a critical approach and a strong reductionist stance ... [and] concluded that building a new prison for women would 'in all probability be counter-productive'.$^{71}$

This was followed by another NSW report in the late 1990s recommending a moratorium on expanding the number of places for women in prison aligned with a focus on prison reduction', but despite this, 'within 20 minutes of the Committee's report being tabled, the government announced that the new women's prison would go ahead'. ${ }^{72}$

While these reports are not recent, and they have not stemmed the tide of continuous growth in the female prison population in Australia (with Stubbs and Baldry describing them as 'long forgotten ${ }^{73}$ ), it is worth noting that there are sound justifications for considering alternatives to imprisonment for the majority of women and that these justifications have been seen as sensible in recent history. Reasonable alternatives are outlined by McCausland and Baldry as including:

69 Sentencing Advisory Council, above n 66, 56.

70 Stathopoulos, above $\mathrm{n}$ 67, 3. This is supported by the recent ALRC inquiry: ALRC, above n 7, 356, 371 .

71 Julie Stubbs and Eileen Baldry, 'In Pursuit of Fundamental Change Within the Australian Penal Landscape. Taking Inspiration from the Corston Report' in Linda Moore et al (eds), Women's Imprisonment and the Case for Abolition: Critical Reflections on Corston Ten Years On (Routledge, 2017) 134.

72 Ibid 136. This is another illustration of the government failing to implement the recommendations of monitoring bodies, as detailed in Chapter 3.

73 Ibid 143. 
- early intervention and diversionary programmes, e.g. police cautioning schemes; bail housing that diverts women from escalating contact with the criminal justice system; [and]

- sentencing alternatives, e.g. home detention, communitybased orders with adequate support to meet parole conditions and avoid incarceration. ${ }^{74}$

\section{Justice Reinvestment}

Justice reinvestment involves redirecting resources from prison infrastructure towards those communities from which a large proportion of the prison population is drawn. The rationale is that if people from these communities are provided with sufficient services and support, they will be less likely to commit crimes that result in imprisonment. As is the case with prison abolition, justice reinvestment requires social change. However, the changes required to implement justice reinvestment are less radical than those required to achieve prison abolition. It nevertheless still recognises both the vulnerability of most imprisoned people and the need to reduce society's reliance on prisons.

Justice reinvestment is a relatively recent approach that seeks to respond to a number of important research findings. ${ }^{75}$ It has been shown that the majority of the prison population is drawn from certain localities. ${ }^{76}$ These localities can be identified using a process termed 'justice mapping' and have high rates of social disadvantage. In addition, recidivism studies show that imprisoning high numbers of people increases crime, rather than reducing it. ${ }^{77}$ Also, as previously detailed, imprisonment is expensive, and the higher the rate of imprisonment, the higher the cost to society. ${ }^{78}$ This, arguably, involves misuse of public money when it does not result in crime reduction.

74 Ruth McCausland and Eileen Baldry, 'Understanding Women Offenders in Prison' in Jane Ireland et al (eds), The Routledge International Handbook of Forensic Psychology in Secure Settings (Routledge, 2017) 37.

75 The term 'justice reinvestment' was first used by Tucker and Cadora in 2003: David Brown et al, Justice Reinvestment. Winding Back Imprisonment (Palgrave Studies in Prisons and Penology, 2016) 18.

76 Some examples of Australian localities were provided in Chapter 1.

77 Sentencing Advisory Council, Does Imprisonment Deter? A Review of the Evidence (2011) 17; Lorana Bartels, 'Criminal Justice Reform Challenges for the Future: It's Time to Curb Australia's Prison Addiction' in Ron Levy et al (eds), New Directions for Law in Australia: Essays in Contemporary Law Reform (ANU Press, 2017) 124.

78 It costs on average $\$ 391.18$ per day to keep someone in prison: Australian Institute of Criminology (AIC), How Much Does Prison Really Cost? Comparing the Costs of Imprisonment with Community Corrections (Research Report No 5, 2018) x. The costs of building new prisons in Australia is referred to in 'Concluding Remarks on Justice Reinvestment' below. 
The justice reinvestment response to these findings is to propose two courses of action: (1) that resources should be reallocated away from prisons and (2) that resources should be invested in the localities where the majority of imprisoned people come from. The first proposal entails not building new prisons and reducing the population of existing prisons. The second requires justice mapping, both to identify the target communities and to assess what services are already available in these localities. ${ }^{79}$ Investment would be in infrastructure and programs that would benefit the community, such as public housing, substance abuse and mental health treatment programs, education and employment assistance. ${ }^{80}$ Justice reinvestment has been argued to be 'Preventative financing, through which policymakers shift funds away from dealing with problems "downstream" (policing, prisons) and towards tackling them "upstream" (family breakdown, poverty, mental illness, drug and alcohol dependency)' ${ }^{81}$

Justice reinvestment has been implemented in over half the states in the United States of America (USA) ${ }^{82}$ and has also been used in the United Kingdom (UK) to a lesser extent. ${ }^{83}$ In the USA, the annual prison budget exceeds US\$53 billion. ${ }^{84}$ Economic pressures have led to 32 states trialling justice reinvestment, with 18 of those having embedded it in legislation. ${ }^{85}$ There was also federal legislation passed in 2009. ${ }^{86}$ The Australian Senate Legal and Constitutional Affairs References Committee (Senate Committee) summarised the success of justice reinvestment in Texas, USA, as follows:

Texas recorded savings of $\$ 443.9$ million in 2008-09 including savings from the cancellation of plans to build new prison units. Savings were reinvested in treatment and diversion programs including $\$ 241$ million to expand the capacity of substance abuse, mental health, and intermediate sanctions facilities and programs. ${ }^{87}$

79 David Brown, Melanie Schwartz and Laura Boseley, 'The Promise of Justice Reinvestment' (2012) 37(2) Alternative Law Journal 96, 97.

80 Ibid 96.

81 Lanning et al cited by ibid 97 .

82 Australian Institute of Crimonology, Justice Reinvestment in Australia: A Review of the Literature (Research Report No 9, 2018) vii.

83 See ibid $24-5$.

84 These are 2013 figures, based on US $\$ 47$ billion used by states and US $\$ 6.7$ billion at the federal level: Brown et al, above n 75, 29.

85 Senate Legal and Constitutional Affairs References Committee, Value of a Justice Reinvestment Approach to Criminal Justice in Australia (2013) 48-61, 49.

86 Criminal Justice Reinvestment Act 2009: AIC, above n 82, 11.

87 Senate Legal and Constitutional Affairs References Committee, above n 85, 51. 
The Australian Institute of Criminology adds to this that as opposed to the projected increase in the prison population of 5,141 people, actual growth in the prison population was only 529 people between January 2007 and December 2008' ${ }^{88}$

There is growing interest in this approach in Australia-particularly for addressing Indigenous over-imprisonment—and it is already being trialled in some communities.

\section{Support for Justice Reinvestment in Australia}

Recent support for justice reinvestment has been expressed at the national level by the ALRC in the context of a report into Indigenous incarceration in 2017, as well as by the Queensland Productivity Commission (QPC) in 2019. The ALRC's report recommended an 'independent justice reinvestment body' and 'trials initiated in partnership with Aboriginal and Torres Strait Islander communities' ${ }^{89}$ The QPC also recommended that the government 'prioritise projects aimed at reducing Indigenous offending' in considering justice reinvestment. ${ }^{90}$

This builds on the continuous support for justice reinvestment for addressing Indigenous over-imprisonment that has been expressed by Aboriginal and Torres Strait Islander Social Justice Commissioners since 2009. ${ }^{91}$ The reasons for this include the high levels of disadvantage in Indigenous communities from which many imprisoned people come. ${ }^{92}$ They also include the 'democratic nature of decision making in the JR [justice reinvestment] methodology', which involves a high level of participation from the communities in the development of solutions. ${ }^{93}$

88 AIC, above $\mathrm{n} 82,21$.

89 ALRC, above n 7, 137-8, Recommendations 4-1, 4-2.

90 Queensland Productivity Commission, above n 13, 151, Recommendation 30.

91 Brown, Schwartz and Boseley, above n 79, 99. See also recommendation 40 of the House of Representatives Standing Committee on Aboriginal and Torres Strait Islander Affairs report on incarceration of Indigenous youth and young adults (Doing Time - Time for Doing. Indigenous Youth in the Criminal Justice System (2011)) and recommendation 9 of the Senate Legal and Constitutional Affairs References Committee, above $\mathrm{n} 85$. This support is also summarised by the ALRC, above $\mathrm{n}$, $138-9$.

92 For example, Indigenous Australians fare much worse than non-Indigenous Australians in the areas of educational attainment, employment and health indicators, and there are more Indigenous people living in overcrowded housing and with children in out-of-home care: Melanie Schwartz, 'Building Communities, Not Prisons: Justice Reinvestment and Indigenous Overimprisonment' (2010) 14(1) Australian Indigenous Law Review 2, 9. This was also documented by the ALRC, above n 7, 61-81.

93 Brown, Schwartz and Boseley, above n 79, 100; ALRC, above n 7, 141. 
Additionally, there is the economic irrationality of the amount of money being spent on Indigenous incarceration. The ALRC estimated that this cost was $\$ 3.9$ billion in $2016 .^{94}$ This irrationality is more acute when it is broken down to the level of particular communities. Schwartz gives the illustration of the town of Papunya, Northern Territory, where 72 out of 308 adults (23 per cent) were in prison during 2007-2008, at a cost of $\$ 3,468,960$ per year. ${ }^{95}$ One does not need to be an economist to imagine what this funding could achieve if it was instead spent on social services for the total Papunya population of 379 adults and children.

This is purely the economic costs. There is also the separate issue of the long-term social costs to individuals and communities of incarceration that are more difficult to measure. ${ }^{96}$

\section{Justice Reinvestment Trials}

The ACT had a four-year justice reinvestment strategy that applied from 2014-18 and included a goal of 'reducing recidivism by $25 \%$ by $2025^{\prime} .{ }^{97}$ It also involved two trials, both tailored to Indigenous people. One provided bail support and the other was for families with 'complex needs'. ${ }^{98}$ The ACT Government announced in February 2019 that they were expanding their commitment to justice reinvestment as part of a new 'Building Communities Not Prisons' strategy, and that as part of this strategy, additional funding has been provided to one of the trials. ${ }^{99}$

One of the earliest justice reinvestment trials to commence in Australia was in the NSW town of Bourke. The town had the following demographic characteristics at the time of the trial: " $t$ ] here are 2,465 people living in the Bourke Shire of which 762 people are Aboriginal and Torres Strait Islander (approximately 30.9\%). The median age of Bourke's Indigenous population is 25 years, approximately $33.7 \%$ of which are children aged

\footnotetext{
94 ALRC, above n 7, 127.

95 Schwartz, above n 92, 4-5.

96 See, eg, the quotation from the submission from Jesuit Social Services to the ALRC, above n 7, 128.

97 ACT Justice and Community Safety Directorate, Reducing Recidivism <https://www.justice.act. gov.au/justice-programs-and-initiatives/reducing-recidivism>.

98 ALRC, above n 7, 135. ACT Government, 'Family-Focused Justice Reinvestment Trial to Help Reduce Over-Representation of Aboriginal and Torres Strait Islanders in Justice System' (Media Release, 26 April 2017).

99 Jordan Hayne and Niki Burnside, 'Canberra's Only Jail is Running Out of Cells, But the Government Wants to "Build Communities Not Prisons”, $A B C$ News (Australia), 15 February 2019.
} 
0 to 14 years'. ${ }^{100}$ The ALRC noted that '[i]t was estimated that the direct costs of Aboriginal juvenile and young adult involvement with the justice system was approximately $\$ 4$ million per year'. ${ }^{101}$

The development phases of the trial commenced in 2012 by the community in partnership with an organisation called 'Just Reinvest NSW' and the Australian Human Rights Commission, ${ }^{102}$ and it was later funded by an Australian Research Council project. ${ }^{103}$ Implementation commenced from 2016 and it is known as the 'Maranguka Justice Reinvestment Project'. ${ }^{104}$ It is too soon for there to be any formal evaluations of the project, but Just Reinvest NSW released some positive statistics in October 2018:

Newly released statistics demonstrate the following changes in Bourke between 2015 and 2017:

- $18 \%$ reduction in the number of major offences reported

- $34 \%$ reduction in the number of non-domestic violence related assaults reported

- $39 \%$ reduction in the number of domestic violence related assaults reported

- $39 \%$ reduction in the number of people proceeded against for drug offences

- $35 \%$ reduction in the number of people proceeded against for driving offences. ${ }^{105}$

The ALRC's report notes that there were also trials being conducted in the Northern Territory, Queensland and South Australia. ${ }^{106}$

100 Just Reinvest NSW, Justice Reinvestment in Bourke <http://www.justreinvest.org.au/justicereinvestment-in-bourke/>.

101 ALRC, above $\mathrm{n} 7,136$. A report was also produced about the changes that occurred in Bourke in 2017 as a result of the project: KPMG, Maranguka Justice Reinvestment Project Impact Assessment (2018).

102 Brown et al, above n 75, 134-5.

103 ALRC, above $\mathrm{n} 7,135$.

104 Ibid 136-7. See also AIC, above n 82, 32-5.

105 Just Reinvest NSW, New Evidence From Bourke <http://www.justreinvest.org.au/new-evidencefrom-bourke/>.

106 ALRC, above $\mathrm{n} 7,136$. There is more detail about some of these contained in AIC, above n 82, 35-40. The Queensland Productivity Commission reports that a trial may be conducted in Cherbourg, Queensland, but the details of the proposed trial were not available: above n 13, 140 . 


\section{Challenges Posed by Justice Reinvestment}

There are some reasons to be cautious about the justice reinvestment approach and several challenges to its implementation were recognised by the Senate Committee and other reports, including:

- lack of clarity about what the strategy means and encompasses ${ }^{107}$

- need for multi-partisan support, because funding within communities would need to be maintained for longer than election cycles for it to be effective ${ }^{108}$

- jurisdictional split of responsibility between federal and state and territory governments for the wide-ranging types of community services that would be required (a whole of government approach would be necessary) ${ }^{109}$

- probability that the level of economic savings would be less in Australia compared to countries with larger populations ${ }^{110}$

- lack of availability of data, which would impact on the mapping and evaluation stages. ${ }^{111}$

Another reason to be cautious of this approach is that it may result in a 'disinvestment' in prison-based services and programs justified under the guise of justice reinvestment. This is a particular danger in 'a cost cutting environment'. ${ }^{112}$ Justice reinvestment is intended to divert resources away from building new prisons and expanding prison capacity, without abolishing prisons entirely. However, because the core concern of the strategy is using resources in a manner that benefits the community and reduces the commission of crime, disinvestment in services for the smaller number of people who are incarcerated may be inconsistent with the aims of justice reinvestment.

107 Senate Legal and Constitutional Affairs References Committee, above n 85, 83-4. See also Brown, Schwartz and Boseley, above n 79, 101.

108 Ibid 85-6. See also Brown, Schwartz and Boseley, above n 79, 101-2.

109 Ibid 86-8. Guthrie et al note that local government would also need to be involved: Jill Guthrie, Michael Levy and Cressida Forde, 'Investment in Prisons: An Investment in Social Exclusion?' (2013)

1(2) Griffith Journal of Human Dignity 254, 261.

110 Ibid 89-91.

111 Ibid 94-9. See also Brown et al, above n 75, 156-7; ALRC, above n 7, 144-5.

112 David Brown, 'Prison Rates, Social Democracy, Neoliberalism and Justice Reinvestment' in Kerry Carrington et al, Crime, Justice and Social Democracy: International Perspectives (Palgrave Macmillan, 2012) 80. Supported by Chris Cunneen et al, Penal Culture and Hyperincarceration. The Revival of the Prison (Ashgate, 2013) 173. 


\section{Concluding Remarks on Justice Reinvestment}

There is no doubt that a hard-headed economic analysis favours justice reinvestment over current expenditure on the expansion of the prison system. As previously detailed, the expenditure on the prison infrastructure expansion is enormous. For example, the Ravenhall prison in Victoria (opened in 2017) reportedly cost $\$ 670$ million to build, ${ }^{113}$ and Victoria has allocated another $\$ 689.5$ million to build another prison (construction commencing in 2019). ${ }^{114}$ Further, once prisons are built imprisoning people is very expensive, costing a total of $\$ 3.8$ billion each year nationally. ${ }^{115}$

As the imprisonment rate continues to grow (as detailed in Chapter 1), without any evidence that it is reducing the crime rate, such expenditure is increasingly recognised to be an unwise use of public funds. ${ }^{116} \mathrm{In}$ addition to curbing the growth of the prison population, justice reinvestment has the added advantage of reducing many societal problems that lead to vulnerable people being over-represented in the prison population.

Notwithstanding the significant advantages of justice reinvestment and the positive indications from the early trials in Australia, there are some challenges posed to implementing it in a federation where imprisonment is the responsibility of the states and territories. The ALRC's recommended national body is designed to address this. ${ }^{17}$

There is also no denying that this approach requires a major shift of resources and significant social change, with the ALRC noting that 'justice reinvestment involves a holistic approach to the drivers of incarceration, which extend beyond justice-related factors to community and social determinants of crime and incarceration'. ${ }^{118}$ An alternative approach that requires changes confined to the criminal justice sphere may be preferable and is considered next.

113 Tom Cowie, 'Inside Victoria's Newest Prison, at Ravenhall, and the Room Where You Don't Want to End Up', The Age (Victoria), 5 July 2017.

114 'Vic Prison Secures Almost \$690m in Budget', SBS News (Australia), 24 April 2018.

115 Bartels, above n 77, 123.

116 The overall crime rate is reducing for unrelated reasons: see, eg, David Brown, 'The Limited Benefit of Prison in Controlling Crime' (2010) 22(1) Current Issues in Criminal Justice 137. For NSW-specific data see Lily Trimboli, NSW Trends in the Age-Specific Rates of Offending, 1995 - 2018 (Issues Paper No 143, NSW Bureau of Crime Statistics and Research, 2019).

117 ALRC, above n 7, 139.

118 Ibid. 


\section{Reductionist Prison Policy}

Prison abolition and justice reinvestment are long-term strategies aimed at shifting the function of imprisonment away from social control towards either minimal use, or if radical social change is achieved, eliminating it entirely. Given that justice reinvestment in Australia is still being debated, and the radical longer-term social change required for prison abolition is not being actively pursued, a relatively short-term solution to reduce the extent to which prison is relied on in Australia is required. A reductionist prison policy is confined to the criminal justice sphere and involves measures such as shortening prison sentences and using alternative sanctions wherever possible. It has the advantage over both the prison abolition and justice reinvestment approaches in that it does not require sweeping social change-something that is both difficult to achieve and unlikely to occur in the current socio-political environment in Australia.

The term 'reductionist' in this context was identified by Rutherford, writing in the 1980s, who categorised approaches of countries to imprisonment as falling into the following three categories:

1. Expansionist-characterised by consistent growth in the prison population and concomitant building of more prisons, expanding existing prisons and recruiting more staff. An example of the application of this approach can be found in the USA since the 1970s. ${ }^{119}$

2. Standstill—characterised by the use of alternative sanctions to replace some prison sentences, replacement of outdated buildings rather than increasing prison capacity, placing a cap on the prison population, and maintaining current operations rather than questioning the fundamental purpose of imprisonment. An example of the application of this approach may be found in the UK in the 1970s-1980s. ${ }^{120}$

3. Reductionist-characterised by reducing the capacity of the system (eg, by closing prisons), early release mechanisms, sentencing focused on lesser sanctions (alternatives to imprisonment), mechanisms to avoid overcrowding and narrowing the scope of the criminal law. ${ }^{121}$ Rutherford gives the examples of Japan and the Netherlands during the period of $1950-75 .{ }^{122}$

119 Andrew Rutherford, Prisons and the Process of Justice: The Reductionist Challenge (Heinemann, 1984) 48-9.

120 Ibid 52-5.

121 Ibid 175-6.

122 Ibid Chapter 6. 
A reductionist approach requires the employment of 'front door' and 'back door' strategies. 'Front door' strategies include using prison as the penalty of 'last resort' in the sentencing regime. 'Back door' strategies include giving people shorter prison sentences and having automatic release on parole after a certain proportion of the sentence has been served. These strategies reflect what Clear and Austin term the iron law of prison populations', which is that 'the total number of prisoners behind bars is purely and simply a result of two factors: the number of people put there and how long they stay. ${ }^{23}$

\section{Application of a Reductionist Policy in Australia}

The following sections discuss the changes that would be required for Australia to implement a reductionist policy (both philosophically and practically) and the obstacles to implementing such a policy.

\section{Philosophical-Level Changes}

Implementation of a reductionist policy in Australia would involve a major shift from the existing trends that are causing the prison population to increase and prisons to be overcrowded. This section will outline existing philosophical-level trends, then consider what might trigger a change at this level.

\section{Existing Trends}

Australia is subject to what Garland has termed the 'culture of

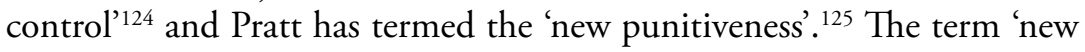
punitiveness' refers to what is often colloquially termed 'law and order' or 'tough on crime' political agendas. In short, this involves a political climate that prioritises retribution at the expense of rehabilitation (this is discussed further in Chapter 6). Tubex et al have documented increasing punitiveness since the 1980s in four Australian states: NSW, Victoria, South Australia and WA. ${ }^{126}$

123 Todd Clear and James Austin, 'Reducing Mass Incarceration: Implications of the Iron Law of Prison Populations' (2009) 3 Harvard Law \& Policy Review 307, 308 (emphasis in original).

124 David Garland, The Culture of Control: Crime and Social Order in Contemporary Society (Oxford University Press, 2001).

125 John Pratt et al, The New Punitiveness: Trends, Theories, Perspectives (Willan Publishing, 2005).

126 Hilde Tubex et al, 'Penal Diversity Within Australia' (2015) 17(3) Punishment \& Society 345. 
Features of this philosophy include reliance on public opinion, particularly victims and the lobby groups they form, in support of reforms, rather than experts and evidence. This is known as 'penal populism'. Garland describes this trend as, ' $[t]$ he importance of research and criminological knowledge is downgraded and in its place is a new deference to the voice of "experience", of "common sense", of "what everyone knows". ${ }^{27}$

There are numerous examples of Australian governments' failure to rely on evidence and expertise. Two examples from Victoria and Queensland will be provided. The Victorian example, from 2010, is provided by Tubex et al:

the [newly elected] government conducted a public opinion survey in conjunction with the state's tabloid newspaper (the Herald Sun), the aim of which was to seek public opinion on the appropriate sentence for a range of offences. At the same time, the survey evidence collected by the state's expert advisory body, the Sentencing Advisory Council, was released, showing that Victorians are more accepting of alternatives to imprisonment than might be expected on the basis of political rhetoric and media headlines. The research undertaken by the Council, however, was dismissed as flawed. ${ }^{128}$

In Queensland, the Sentencing Advisory Council was issued terms of reference on minimum standard non-parole periods. The Council's 2011 report stated that the majority of members were against the introduction of such a scheme and concluded that ' $\mathrm{t}]$ he absence of strong evidence that minimum standard non-parole period schemes are effective, and achieve better sentencing outcomes than existing approaches, has led the Council to question the merits of introducing a minimum standard nonparole period scheme in this State'. ${ }^{129}$ Despite this expert body's opinion, the Queensland Government has introduced a non-parole period of 25 years for murdering a police officer and a requirement that at least 80 per cent of the term of drug trafficking sentences must be served. These reforms were passed in conjunction with the abolition of the Queensland Sentencing Advisory Council. ${ }^{130}$ The abolition of an expert advisory body is an extreme reaction to unwanted advice. ${ }^{131}$

127 Garland, above n 124, 13. See also John Pratt, 'Penal Populism and the Contemporary Role of Punishment' in Thalia Anthony and Chris Cunneen (eds), The Critical Criminology Companion (Hawkins Press, 2008) 268.

128 Tubex et al, above n 126,355 .

129 Sentencing Advisory Council, Minimum Standard Non-Parole Periods. Final Report (2011) x, xv. 130 Andrew Trotter and Harry Hobbs, 'The Great Leap Backward: Criminal Law Reform with the Hon Jarrod Bleijie' (2014) 36(1) Sydney Law Review 1, 15.

131 Queensland re-established the Sentencing Advisory Council in 2016: Queensland Sentencing Advisory Council, Governance <https://www.sentencingcouncil.qld.gov.au/about-us/governance>. 
A further review of minimum standard parole periods in Queensland in 2016 recommended that judges should 'have the discretion to depart from that mandatory period' in certain circumstances (Recommendation 7). ${ }^{132}$ This recommendation was not supported by the government, with the response to the review noting, '[i]n our view the potential risk to community safety by implementing Recommendation 7 outweighs the benefits it could bring to the new parole system and as such, it is not intended to remove mandatory non-parole periods at this point in time'. ${ }^{133}$ Freiberg et al note that ' $[t]$ his is particularly striking, given that NSW and South Australia ... do incorporate "special circumstances" provisions. ${ }^{134}$

As will be seen further in the discussion of practical strategies for applying a reductionist prison strategy (under 'Practical Strategies for Change in Custodial Sentencing Policies'), evidence-based legislative reform informed by organisations such as Sentencing Advisory Councils will need to be undertaken across Australia if a reductionist policy is to have any hope of being achieved.

\section{Potential Triggers for Change}

An economic argument may be employed to achieve philosophical-level change and is likely to be the strongest impetus for change. Given that the costs of imprisonment are spiralling, and given that recidivism rates are high, imprisonment may be construed as a misuse of public funds. It is helpful when organisations such as Productivity Commissions highlight that investing in prisons does not help to make the community safer. For example, the Queensland Productivity Commission has recently reported that 'the costs of imprisonment are likely to outweigh the benefits, with increasing imprisonment working to reduce community safety over time'. ${ }^{135}$

The economic argument is part of the attraction of justice reinvestment and has received support from conservative politicians in the USA as a result, especially in times of financial crisis. ${ }^{136}$ Justice reinvestment is likely to be a longer-term goal due to the investment in social services

132 Walter Sofronoff, Queensland Parole System Review, Final Report (Department of Justice and Attorney-General, 2016) 105-6.

133 Queensland Government, Response to Queensland Parole System Review Recommendations (2017) $<$ https://parolereview.premiers.qld.gov.au/assets/government-response-to-qpsr-recommendations.pdf>. 134 Arie Freiberg et al, 'Parole, Politics and Penal Policy' (2018) 18(1) QUT Law Review 191, 202.

135 Queensland Productivity Commission, above n 13, x.

136 Brown, Schwartz and Boseley, above n 79, 98. 
required and the complexity of implementing this change in a federation (as previously discussed in this chapter, under 'Justice Reinvestment'). However, the economic argument is certainly also worth employing as a strategy to combat overcrowding and to work towards a reductionist prison policy. ${ }^{137}$

Compliance with international human rights law, particularly art 10(3) of the ICCPR requiring the purpose of imprisonment to be rehabilitation and social reformation, is a potential lever for arguing that a change in philosophy is required. However, it is not a strong lever, given that Australia has a tendency to disagree with, or ignore, the Concluding Observations or Comments of UN treaty monitoring bodies (as discussed in Chapter 2). Moreover, Australia does not have national human rights legislation, nor state and territory statutory human rights protections across all states and territories (only Victoria, the ACT and Queensland have such statutes) (detailed in Chapter 5). The ratification of the OPCAT, and the monitoring regime this will introduce, offers the most potential for a shift towards human rights compliance, but this may not result in a broad enough philosophical-level shift in the approach to criminal justice.

Another possibility is that there will be a crisis in one or more prisons that precipitates change. ${ }^{138}$ For example, violence by prison staff towards imprisoned people in the Bathurst prison in NSW in the early 1970s culminated in a riot in 1974. A number of people were injured (including by guns being fired from the towers) and a section of the prison was destroyed. ${ }^{139}$ This led to a Royal Commission headed by Justice Nagle of the NSW Supreme Court ${ }^{140}$ which 'essentially verified prisoners' accounts of events at Bathurst'. ${ }^{141}$ This led to a number of improvements in the NSW prison system, including a shift away from an entrenched culture of use of systematic violence by prison staff, ${ }^{142}$ and legislative changes across

137 See, eg, the 2006 study that found that to reduce the NSW burglary rate by 10 per cent would require a 34 per cent increase in the number of burglars imprisoned, at a cost of \$26 million per year: Don Weatherburn, Jiuzhao Hua and Steve Moffatt, 'How Much Crime Does Prison Stop? The Incapacitation Effect of Prison on Burglary', Crime and Justice Bulletin (NSW Bureau of Crime Statistics and Research, 2006).

138 A United Kingdom example is riots in 1990 that led to a major inquiry headed by Lord Woolf: Andrew Coyle, The Prisons We Deserve (Harper Collins Publishers, 1994) 5, 156-60.

139 David Brown, 'The Nagle Royal Commission 25 Years On. Gaining Perspective on Two and a Half Decades of NSW Prison Reform' (2004) 29(3) Alternative Law Journal 135, 135.

140 Justice Nagle, Report of the Royal Commission into NSW Prisons (Government Printer, 1978).

141 Brown, above n 139, 136.

142 Ibid 137. 
other Australian jurisdictions. ${ }^{143}$ However, a proactive rather than reactive change in philosophy will avoid the tragic human cost of a crisis. The aim of the OPCAT is preventive, as discussed in detail in Chapter 3, and this approach is preferable. In short, the required changes at the philosophical level are difficult to envisage occurring in the short term in Australia. Nevertheless, they are necessary to reduce reliance on imprisonment.

\section{Practical Strategies for Change in Custodial Sentencing Policies}

A number of practical strategies would also need to be employed to implement a reductionist prison policy in Australia. These include amendments to state and territory sentencing legislation and generating support from the general public. ${ }^{144}$

\section{Sentencing Law Reform}

The changes to sentencing laws needed to implement a reductionist policy would be sweeping, given that, as noted above, the trend since the 1980s has been for criminal sanctions to get 'tougher'. ${ }^{145}$ Another challenge is that there are sentencing laws at the federal, state and territory level. ${ }^{146}$ Moreover, nine different governments would have to undertake a legislative reform program to achieve national-level implementation.

A cataloguing of the sentencing law changes that would be required is beyond the scope of this book. Rather, this section considers four trends in sentencing reform that illustrate the types of sentencing laws that need to be countered because they are in direct opposition to a reductionist policy:

143 These are summarised by Matthew Groves, 'Ombudsmen's Jurisdiction in Prisons' in Marc Hertogh and Richard Kirkham (eds), Research Handbook on the Ombudsman (Edward Elgar Publishing, 2018) 324-5 n 24.

144 Another major area that could be addressed is bail laws because bail law reforms are increasing the number of people remanded in custody before they have been sentenced ( 33 per cent of the Australian prison population is unsentenced: Australian Bureau of Statistics, Prisoners in Australia 2019 (5 December 2019) Table 1). For a discussion of the contribution of bail to prison numbers see Weatherburn, above $\mathrm{n} 8$. One of the strategies for reducing overcrowding in prisons recommended by the United Nations Office on Drugs and Crime is 'reducing pretrial detention': United Nations Office on Drugs and Crime, Handbook on Strategies to Reduce Overcrowding in Prisons (United Nations, 2013) Chapter E. However, consideration of bail laws is outside the scope of this book. For an up-to-date catalogue of recent reforms see Lorana Bartels et al, 'Bail, Risk and Law Reform: A Review of Bail Legislation Across Australia' (2018) 42 Criminal Law Journal 91.

145 Tubex et al, above n 126.

146 Federal sentencing laws cover approximately 10 per cent of crime: Geraldine Mackenzie, Nigel Stobbs and Jodie O'Leary, Principles of Sentencing (Federation Press, 2010) 14. 
(1) 'particularism', (2) abolishing alternatives to prison, (3) restricting parole (including imposing mandatory sentences) and (4) introducing terrorism or organised crime offences.

It is worth briefly noting that Bagaric has proposed uniform national sentencing laws, arguing this would lead to less use of imprisonment. ${ }^{147}$ If this suggestion were adopted, it might 'assist to depoliticise the process of sentencing reform' and allow for the laws to become more evidencebased. ${ }^{148}$ This is because it reduces the need for politicians to introduce sentencing reforms directly responding to the demands of their constituents by relocating reform to the national level. However, there is no guarantee that federal politicians will not become caught up in similar pressures. As will be seen shortly, there are mandatory minimum sentences for Commonwealth terrorism offences. There are also significant challenges associated with the legislative harmonisation, even in areas of law that are less politicised than sentencing law. ${ }^{149}$

Australian jurisdictions have been enacting additional particular offences, often in situations where there are already criminal laws in place, to deal with the behaviour in question. Loughnan terms this trend 'particularism', which she defines as 'a phenomenon in the drafting of offences where the particular wording of offences provides "the definitional detail that merely exemplifies rather than delimits wrongdoing"'. ${ }^{150}$ An example of this is the 2008 NSW offence of rock throwing to counteract behaviour such as throwing rocks from freeway overpasses onto the cars passing below. ${ }^{151}$

147 Mirko Bagaric, 'An Argument for Uniform Australian Sentencing Law' (2013) 37(1) Australian Bar Review 40, 41.

148 Ibid 50-1.

149 Harmonisation has not been achieved in evidence law, despite the fact that discussions about the desirability of harmonisation commenced in 1979 with an ALRC inquiry that produced draft legislation in 1985: ALRC and New South Wales Law Reform Commission, Uniform Evidence Law (2006) [1.3]. For an overview of the history of uniform evidence law in Australia see ibid Chapter 1. For a discussion of the current situation see Stephen Odgers, 'Uniform Evidence Law at 21' (2017) 28(3) Current Issues in Criminal Justice 311; Andrew Roberts and Jeremy Gans (eds), Critical Perspectives on the Uniform Evidence Law (The Federation Press, 2017). Harmonisation of legislation across Australia has been considered in relation to criminal responsibility with the drafting of a Model Criminal Code in the 1990s; see further Arlie Loughnan, "The Very Foundations of Any System of Criminal Justice": Criminal Responsibility in the Australian Model Criminal Code' (2017) 6(3) International Journal for Crime, Justice and Social Democracy 8.

150 Arlie Loughnan, 'Drink Spiking and Rock Throwing. The Creation and Construction of Criminal Offences in the Current Era' (2010) 35(1) Alternative Law Journal 18, 20.

151 Another example is Queensland's 'anti-hooning' legislation: Andrew Trotter and Harry Hobbs, 'The Great Leap Backward: Criminal Law Reform with the Hon Jarrod Bleijie' (2014) 36(1) Sydney Law Review 1, 15. 
The NSW Attorney-General recognised that there were other offences (such as assault) that could be employed to deal with such behaviour. ${ }^{152}$ However, the NSW Government insisted on introducing an offence that Loughnan argues is not 'morally' but rather merely 'factually distinct' from existing offences. In addition to expanding the scope of the criminal law, she argues that this reduces the internal logic and order of the criminal law'. ${ }^{153}$ This trend towards particularism should be reversed.

Australian jurisdictions have been abolishing alternative sanctions to prison. ${ }^{154}$ For example, the Victorian Government abolished home detention in 2012 because 'it was perceived (particularly in the media) as a "soft punishment" and not a substitute for jail'. ${ }^{155}$ Between 2011 and 2014, the Victorian Government phased out suspended sentences ${ }^{156}$ and they were abolished in NSW in 2017. ${ }^{157}$

It has been observed that in South Australia:

no major party parliamentarian debates non-custodial alternatives, lest they be seen to be 'soft on crime'. The only debates are about what sort of expansions to prison capacity should be considered, not whether there needs to be an expansion to capacity, or how much longer a new penalty of imprisonment will be for a certain offence rather than whether a non-custodial alternative is more effective. ${ }^{158}$

Some Australian jurisdictions have tightened eligibility for parole, and many have introduced minimum non-parole periods (also known as mandatory sentencing because the prescribed non-parole period is

152 Loughnan, above n 150, 20.

153 Ibid 20-1.

154 This is inconsistent with one of the strategies for reducing overcrowding in prisons recommended by the United Nations Office on Drugs and Crime, 'introducing alternatives to imprisonment': United Nations Office on Drugs and Crime, above n 144, Chapter B Section 6.

155 Michelle McDonnell and James Farrell, 'Tough, Tougher, Toughest? A New Government's Approach to Sentencing Laws in Victoria' (2012) 37(3) Alternative Law Journal 238, 239.

156 Sentencing Advisory Council, Abolished Sentencing Orders <https:/www.sentencingcouncil. vic.gov.au/about-sentencing/abolished-sentencing-orders $>$. For a history of their use in Victoria see Arie Freiberg, 'Suspended Sentences in Australia: Uncertain, Unstable, Unpopular, and Unnecessary Alternatives to Imprisonment' (2019) 82(1) Law and Contemporary Problems 81, 86-8.

157 Freiberg explains that this type of sentence 'is generally regarded as a sentence of imprisonment that is imposed but not immediately executed ... It may or may not have conditions attached and can vary in length from maximum periods of two years to indefinitely': Freiberg, above n 156, 83. In 2019, the Queensland Productivity Commission recommended that home detention be 'established' and non-custodial sentences be 'encouraged': above n 13, Recommendation 9.

158 Tubex et al, above n 126, 359 . 
the amount of time the person must spend in prison). ${ }^{159}$ Mandatory sentencing legislation severely restricts the discretion that traditionally characterises sentencing decisions in Australia. ${ }^{160}$ In particular, it has been shown to have a disproportionate impact on Indigenous people. ${ }^{161}$ Examples identified by Freiberg et al ${ }^{162}$ include:

- Terrorism offences under Commonwealth legislation ${ }^{163}$

- Murder (with a higher sentence if the victim was a police officer), ${ }^{164}$ firearms offences ${ }^{165}$ and for members of 'criminal organisations' in Queensland $^{166}$

- Murder ${ }^{167}$ and sex offences in the Northern Territory ${ }^{168}$

- Offences involving 'gross violence' and specific victims, such as 'emergency workers or custodial officers on duty unless "special circumstances" exist' in Victoria. ${ }^{169}$

Many of the legislative changes to parole stem from inquiries, such as the inquiry that followed the rape and murder of Jill Meagher by Adrian Bayley while on parole while in September 2012 in Victoria, a crime that gained a particularly high profile. ${ }^{70}$ Former High Court Judge Callinan was asked to review the operations of the Victorian Adult Parole Board. His report reflected the view that people who commit crimes forfeit their rights, with

159 Freiberg et al note that ' $\mathrm{t}]$ here are two ways in which such schemes can be created. One is a defined scheme, under which the non-parole period is specifically prescribed in legislation ... The other is to set a percentage of the head sentence that must be served before the offender is eligible for parole': Freiberg et al, above n 134, 198-9. This is inconsistent with one of the strategies for reducing overcrowding in prisons recommended by the United Nations Office on Drugs and Crime, 'removing mandatory minimum sentencing provisions': United Nations Office on Drugs and Crime, above n 144, Chapter B Section 3.

160 Mackenzie, Stobbs and O'Leary, above n 146, 1. This was noted by the Queensland Productivity Commission in recommending a review by the Queensland Sentencing Advisory Council (within 24 months) of legislated limits on judicial discretion to 'to ensure they are serving their intended purpose': Queensland Productivity Commission, above n 13, 299, 303, Recommendation 12.

161 Freiberg et al, above n 134, 201-2.

162 Ibid 200-1.

163 Crimes Act 1914 (Cth) s 19AG; Criminal Code 1995 (Cth) ss 80, 91.

164 Criminal Code Act 1899 (Qld) ss 305(1)-(2).

165 Weapons and Other Legislation Amendment Act 2012 (Qld).

166 Criminal Law (Criminal Organisations Disruption) Amendment Act 2013 (Qld).

167 Sentencing Act 1995 (NT) ss 54(1)-(2).

168 Ibid s 55 .

169 Freiberg et al, above n 134, 201. See Crimes Act 1958 (Vic) ss15A, 15B. The Australian Capital Territory is the exception and has been resisting the introduction of mandatory sentences: Bartels, above $\mathrm{n} 77,126$.

170 Freiberg et al, above n 134, 194-5. See also Monique Moffa, Greg Stratton and Michele Ruyters, 'Parole Populism: The Politicisation of Parole in Victoria' (2019) 31(1) Current Issues in Criminal Justice 75. 
the report noting that 'convicted criminals are intentionally denied rights. It is an important object of the justice system that they are so denied'. ${ }^{171}$ The report went on to recommend that the Board continue to be exempt from the Charter of Human Rights and Responsibilities Act 2006 (Vic). ${ }^{172}$

Another illustration of laws that reduce eligibility for parole are the socalled 'no body, no parole laws'. ${ }^{173}$ As the name suggests, '[ $t$ ] hese laws require a parole authority to take into account an offender's cooperation with, or assistance to, authorities with respect to disclosing the whereabouts of the deceased's body'. ${ }^{174}$ They have been introduced in South Australia, Victoria and the Northern Territory. ${ }^{175}$ Freiberg et al note that " $[t]$ he "no body, no parole law" have the effect of superseding the judge's original decision and possibly extending the offender's sentence by many years'. ${ }^{176}$

These types of parole reforms will contribute to the maintenance of an overcrowded prison system, among other problems. If this trend continues, it will undoubtedly thwart the realisation of a reductionist policy in Australia.

The final trend to note is that, according to McGarrity, 'extraordinary measures' introduced to address the 'extraordinary threat of terrorism' have become 'normalised' since $9 / 11$, and are expanding into general criminal law. ${ }^{177}$ An example is legislation intended to control motorcycle clubs. This legislation violates the fundamental human rights of people impacted by it - particularly, the right to freedom of association and right not to have one's liberty restricted unless a court has made a determination of guilt. ${ }^{178}$

171 Ian Callinan, Review of the Parole System in Victoria (2013) 69. See also the discussion in Freiberg et al, above n 134, 196.

172 Ibid 91, Measure 8. This recommendation was adopted: 'Regulation 5(a) of the Charter of Human Rights and Responsibilities (Public Authorities) Regulations 2013 declares that the Board is not a public authority for the purposes of the Charter of Human Rights and Responsibilities. This has the effect of excluding the Board from the operation of the Charter. In particular, this means that the Board is not subject to the prohibitions against acting in a way that is incompatible with a human right or against failing to give proper consideration to a relevant human right in making a decision': Adult Parole Board Victoria, Parole Manual Adult Parole Board of Victoria (Adult Parole Board of Victoria, 2018) 9.

173 Freiberg et al, above n 134, 212.

174 Ibid.

175 See discussion by ibid 212-13.

176 Ibid 213.

177 Nicola McGarrity, 'From Terrorism to Bikies. Control Orders in Australia' (2012) 37(3) Alternative Law Journal 166, 169.

178 Ibid 168. See also Nicola McGarrity and Jessie Blackbourn, 'Anti-Terrorism Laws and Human Rights' in Leanne Weber et al (eds), The Routledge International Handbook of Criminology and Human Rights (Routledge, 2016). 
McGarrity summarises the operation of the legislation as follows:

First an organisation may be declared to be a serious organised crime organisation ... the making of a declaration enlivens the second stage of the process. That is, a control order may be issued by a court in relation to a member or former member of the declared organisation ... The purpose of a control order is to impose limits on a person's liberty so as to prevent them from being a threat to the community ... It is a criminal offence for a person to breach the terms of a control order. ${ }^{179}$

This type of legislation has been in force in South Australia since 2008, and in NSW, the Northern Territory and Queensland since 2009. ${ }^{180}$ Western Australia also passed such legislation in 2012, and NSW revised theirs in 2012. ${ }^{181}$

These are just a few examples of the trends that would need to be countered to achieve a reductionist policy in Australia. The task is substantial, to say the least.

\section{Generate Public Support}

In addition to these changes to legislation and the policymaking process, the general public needs to come to understand the need for, and support, a reduction in imprisonment. ${ }^{182}$ It is first necessary to consider what public attitudes to the use of imprisonment are. The wide divergence that can occur on this subject is aptly shown by some research about the difference in attitudes about the use of imprisonment between Finns (Finland's imprisonment rate is one of the lowest in the world, at 51 per 100,000 ) and Texans in the USA (where the national imprisonment rate is the highest in the world, at 655 per 100,000). ${ }^{183}$ Houseman gives the following example:

179 McGarrity, above n 177, 166

180 Serious and Organised Crime (Control) Act 2008 (SA); Crimes (Criminal Organisations Control) Act 2009 (NSW); Serious Crime Control Act 2009 (NT); Criminal Organisation Act 2009 (Qld). A number of jurisdictions amended their legislation following a High Court challenge to the Queensland legislation that found it to be constitutionally valid: Assistant Commissioner Condon $v$ Pompano Pty Ltd (2013) 252 CLR 38. See discussion by Luke McNamara and Julia Quilter, 'High Court Constitutional Challenges to Criminal Law and Procedure Legislation in Australia' (2018) University of New South Wales Law Journal 1047, 1070-1.

181 Criminal Organisations Control Act 2012 (WA); Crimes (Criminal Organisations Control) Act 2012 (NSW).

182 One of the strategies for reducing overcrowding in prisons recommended by the United Nations Office on Drugs and Crime is 'gaining public support': United Nations Office on Drugs and Crime, above n 144, Chapter A Section 4.

183 International Centre for Prison Studies, World Prison Brief <http://www.prisonstudies.org/ world-prison-brief>. 
Individuals were questioned about an appropriate sentence for a repeat burglar who is twenty-one years of age. In Finland, seventeen-and-a-half percent of those surveyed were in favour of imprisonment. In contrast, fifty-six percent of Americans favoured imprisonment for the hypothetical offender. ${ }^{184}$

In Australia, there have been numerous studies of public opinions about sentencing and levels of punitiveness at the national level and in specific states and territories. In brief, this research has found that there are not large differences in public attitudes across jurisdictions (despite legal differences around Australia). ${ }^{185}$ People are more likely to consider leniency when it is a person's first time offence. ${ }^{186}$ They also believe that imprisonment is best reserved for serious offences, with non-custodial options available for other types of crimes. ${ }^{187}$

In one Victorian study, the respondents were aware of the high cost of imprisonment. Bartels et al summarise the findings as follows:

Specifically, 51 percent of respondents agreed that 'we need to find alternatives to prison to reduce the high cost to the community of keeping people in prison' was 'very important', while 69 percent said it was 'very important' that 'taxpayer money should be used on programs that reduce crime in the first place rather than on prison'. ${ }^{188}$

Based on these public attitudes, there are two themes that can be harnessed to support a reduction in imprisonment. The first is the general support for reserving imprisonment for the most serious offences and exploring non-custodial alternatives for other types of criminal offences. This runs counter to the abolition of these non-custodial sanctions by legislatures around the country. The second is to emphasise the high cost

184 Lilith Houseman, 'Reducing Reliance on Incarceration in Texas: Does Finland Hold Answers?' (2010) 46 Texas International Law Journal 209, 228.

185 Lorana Bartels, Robin Fitzgerald and Arie Freiberg, 'Public Opinion on Sentencing and Parole in Australia' (2018) 65(3) Probation Journal 269, 272.

186 For example, a Victorian study found, '[f] or first-time burglars, respondents were most likely to nominate rehabilitation as the most important sentencing purpose for both young (62 percent) and adult ( 50 percent) offenders, followed by punishment (13 percent and 23 percent respectively). For repeat burglars, by contrast, the most important purpose was punishment for both young and adult offenders ( 40 percent and 51 percent), followed by rehabilitation for young offenders (26 percent) and incapacitation for adult offenders (20 percent)': ibid 273.

187 Ibid. Based on a NSW study.

188 Ibid 272. 
of imprisonment and that this does not necessarily represent good value for money. This is something that has helped justice reinvestment to gain some traction in other countries. ${ }^{189}$

Bartels has argued that it is important to educate the public on the facts that 'prison is not a particularly effective crime reduction tool ... [and] that crime is decreasing, and has been doing so for some time'. ${ }^{190}$ The Northern Territory Ombudsman has also recommended shifting the focus of public debate surrounding imprisonment away from punishment and towards rehabilitation, with particular emphasis on the fact that rehabilitation is more likely to make the community safer. The Ombudsman observed that the government has a responsibility 'to convince members of the public that change can also bring benefits in terms [of] assisting individuals to play a more constructive role in society and at the same time minimise crime in the future. ${ }^{191}$

Another aspect of a campaign to garner public support, advocated by Scott, could be to increase public awareness about the harm suffered by people in prison. For example, by providing people who have been incarcerated with an opportunity to speak about their experiences. ${ }^{192}$ The media attention given to the reports of monitoring bodies referred to in Chapter 3 may assist with this endeavour. Implementation of the OPCAT will improve the transparency of monitoring in Australia, as well as opening up Australia to the scrutiny of the SPT.

In summary, if the public are better educated, and a level of public empathy for imprisoned people can be generated, the public may be more likely to support reforms intended to reduce the use of imprisonment as a sanction. ${ }^{193}$

189 It is also one of Houseman's two 'prongs' of a public education campaign when suggesting what Texas may learn from Finland: see Houseman, above n 184, 229-30.

190 Bartels, above n 77, 127.

191 Ombudsman Northern Territory, Ombudsman NT Investigation Report. Women in Prison II Alice Springs Women's Correctional Facility (2017) vol 1, 45.

192 Scott, above n 44, 316-17.

193 Bartels notes that ' $r$ ] esearch from both Australia and overseas demonstrates that the more educated people are about crime, the less punitive they become': Bartels, above n 77, 128. 


\section{Conclusion}

The prison population in Australia is undergoing unmitigated growth and, while jurisdictions are investing in new prisons, capacity has not kept pace with this growth. Australia has reached the point where even shipping containers and 'rapid build' prisons with dormitory accommodation are not keeping pace with the growth in prison population. Bartels describes this as an 'addiction to prisons'. ${ }^{194}$

The corollary of this growth is significant overcrowding. Human rights violations in overcrowded prisons are not risks, they are guaranteed. There is evidence that sharing prison cells leads to increased intimidation; bullying; violence and potential for torture or cruel, inhuman or degrading treatment or punishment. This will be of interest to the SPT when it visits Australia. Overcrowded prisons also cannot provide adequate services and there are increased risks of riots.

There are three potential strategies for reducing Australia's reliance on imprisonment. The first-prison abolition-has long-term and middleterm aims and it has been argued that the latter may receive some traction in relation to women's imprisonment. The second-justice reinvestment-is already being trialled in some communities and has particular advantages as a strategy for addressing the over-imprisonment of Indigenous Australians. However, it is not without practical challenges when it comes to implementation. Both of these strategies involve wholesale social change of a scale that Australia may not be ready for.

This chapter has therefore argued that a reductionist prison policy should be implemented in Australia because it is the most realistic option for reducing reliance on imprisonment as a prerequisite to human rights compliance. Such a policy is unlikely to achieve changes quickly. It will involve incremental change over a number of years, particularly to achieve the philosophical changes and generate the public support that will need to accompany the substantial legislative reform agenda that will be required across all jurisdictions. Perhaps the implementation of the monitoring requirements under the OPCAT will provide an incentive for the necessary changes? 
This text is taken from Towards Human Rights Compliance in Australian Prisons, by Anita Mackay, published 2020 by ANU Press, The Australian National University, Canberra, Australia.

doi.org/10.22459/THRCAP.2020.04 